\title{
Pengaruh Jenis Bahan Kemasan Terhadap Kualitas Organoleptik Dan Daya Simpan Tempe Kedelai
}

\author{
Andi Liuspiani ${ }^{1}$, Indra Himayatul Asri ${ }^{2}$, Yuniar Lestarini ${ }^{3}$, Zalia Muspita ${ }^{4}$, Muhammad \\ Husni $^{5}$ \\ ${ }^{12345}$ Program Studi Pendidikan Biologi Universitas Hamzanwadi \\ *Email: Alvianiapandi1997@gmail.com
}

\begin{abstract}
Abstrak: Penelitian tentang daun sebagai pembungkus tempe masih terbatas, padahal seperti diketahui Indonesia merupakan negara yang memiliki kekayaan hayati terutama tumbuhan berdaun lebar yang dimanfaatkan sebagai pembungkus tempe. Tujuan penelitian ini adalah untuk mengetahui pengaruh jenis bahan kemasan terhadap kualitas organoleptik dan daya simpan tempe kedelai. Penelitian ini dilaksanakan di Dusun Teniki, Desa Gelanggang, Kecamatan Sakra Timur, Kabupaten Lombok Timur. Jenis penelitian ini adalah penelitian eksperimen. Subjek dalam penelitian ini mencakup semua tempe kedelai yang dibungkus dari daun pisang sebagai (kontrol), daun pepaya dan daun talas sebagai (eksprimen) untuk pengujian kualitas organoleptik dan daya simpan tempe kedelai. Penelitian ini menggunakan rancangan acak lengkap (RAL), dengan 3 kali pengulangan kemudian diuji kepada 20 orang panelis. Analisis data menggunakan ANAVA satu jalan sel sama dengan taraf signifikansi 5\% pada hasil analisis dengan indikator rasa $\mathrm{F}$ hitung $>\mathrm{F}$ tabel $(4,99>3,15)$, indikator warna $\mathrm{F}$ hitung $\langle\mathrm{F}$ tabel $(0,10<3,15)$, indikator aroma $\mathrm{F}$ hitung $>$ $\mathrm{F}$ tabel $(3,89>3,15)$, indikator tekstur $\mathrm{F}$ hitung $>\mathrm{F}$ tabel $(5,81>3,15)$. Jadi dapat disimpulkan bahwa ada pengaruh jenis bahan kemasan terhadap kualitas organoleptik yang meliputi rasa, aroma dan tekstur tempe kedelai sedangkan untuk warna tidak ada pengaruh, kemudian untuk daya simpan tempe kedelai yang paling lama yaitu daun pisang lama penyimpanan 4 hari sedangkan daun talas dan daun pepaya lama penyimpanan 3 hari.
\end{abstract}

Kata Kunci: Organoleptik, Jenis Kemasan, Daya Simpan, Kedelai

Abstrack: Research on leaves as a wrapper for tempe is still limited, even though as it is known, Indonesia is a country that has biological wealth, especially broad leaf plants that are used to wrap tempe. The purpose of this study was to determine the effect of the type of packaging material on the organoleptic quality and shelf life of soybean tempe. This research was conducted in Teniki Hamlet, Gelanggang Village, East Sakra District, East Lombok Regency. This type of research is experimental research. Subjects in this study included all soybean tempe wrapped in banana leaves as (control), papaya leaves and taro leaves as (experiment) for testing the organoleptic quality and shelf life of soybean tempe. This study used a completely randomized design (CRD), with 3 repetitions and then tested on 20 panelists. Data analysis using ANOVA one way cell is equal to a significance level of $5 \%$ in the analysis results with the taste indicator $\mathrm{F}$ count $>\mathrm{F}$ table $(4.99>3.15)$, color indicator $\mathrm{F}$ count $<\mathrm{F}$ table $(0.10<3.15)$, aroma indicator $\mathrm{F}$ count $>\mathrm{F}$ table $(3.89>3.15)$, texture indicator $\mathrm{F}$ count $>\mathrm{F}$ table $(5.81>3.15)$. So it can be concluded that there is an effect of the type of packaging material on the organoleptic quality which includes the taste, aroma and texture of soybean tempe, while for color there is no effect, then for the longest shelf life of soybean tempe, namely banana leaves with 4 days storage time while taro leaves and papaya leaves. 3 days storage time.

Keyword: Organoleptic, Type of Package, Storage Capacity, Soybean

\section{LATAR BELAKANG}

Indonesia merupakan negara dengan kekayaan sumber daya alam pangan yang berlimpah salah satunya adalah biji-bijian yang 
memiliki zat gizi untuk memenuhi kebutuhan gizi dalam diet atau menu sehari-hari. Salah satu keunggulan biji-bijian adalah harganya relatif murah dengan kandungan gizi yang baik untuk kesehatan dan mengandung berbagai mineral yang dibutuhkan oleh tubuh. Pada saat ini sudah banyak olahan dari biji-bijian salah satunya adalah tempe. Biji-bijian yang biasa digunakan dalam pembuatan tempe adalah biji kedelai (mufidah, dkk. 2018:21-22). Kedelai (glycine max l.) Merupakan tanaman pangan yang penting sebagai sumber protein nabati, kedelai juga merupakan komoditas strategis di indonesia karena merupakan salah satu tanaman pangan penting setelah beras dan jagung (bisyria, dkk. 2015: 138).

Tempe merupakan makanan tradisional yang telah lama dikenal di Indonesia. Indonesia merupakan negara produsen tempe terbesar di dunia dan menjadi pasar kedelai terbesar di Asia. Sebanyak 50\% kedelai di Indonesia dikonsumsi dalam bentuk tempe, $40 \%$ dalam bentuk tahu, dan $10 \%$ dalam bentuk produk lain (seperti tauco, kecap dan lain-lain). Konsumsi tempe rata-rata per orang per tahun di Indonesia saat ini diduga sekitar 6,45 kg (Razie \& Widawati, 2018: 95).

Tempe merupakan makanan tradisional hasil fermentasi dari aktivitas jamur Rhizopus sp. Tempe dengan kualitas baik mempunyai ciri-ciri berwarna putih bersih yang merata pada permukaannya, memiliki struktur yang homogen dan kompak, serta berasa, dan beraroma khas tempe. Proses pembuatan tempe meliputi pencucian kedelai, perebusan, perendaman, pengupasan kulit kedelai, inokulasi, pembungkusan dan fermentasi. Tempe merupakan salah satu produk berbasis kedelai yang memiliki manfaat, baik dari segi nutrisi maupun kesehatan. Beberapa penelitian menunjukkan bahwa nutrisi tempe lebih mudah dicerna, diserap dan dimanfaatkan oleh tubuh dibandingkan dengan nutrisi kedelai yang dikonsumsi secara langsung (Winanti, dkk.2014: 40).

\section{METODE PENELITIAN}

Penelitian ini bertempat di Dusun Teniki, Desa Gelanggang, Kecamatan Sakra Timur, Kabupaten Lombok Timur, NTB. Subjek dalam penelitian ini adalah semua tempe kedelai yang dibungkus dari daun pisang (kontrol), daun pepaya dan daun talas (eksperimen) untuk pengujian kualitas organoleptik dan daya simpan tempe kedelai. penelitian ini menggunakan jenis penelitian eksperimen dengan menggunakan tiga perlakuan yaitu tempe yang dikemas dengan daun pisang, tempe yang dikemas menggunakan daun pepaya dan tempe yang dikemas dengan daun talas. Rancangan penelitian ini menggunakan rancangan acak lengkap (RAL), dengan tiga perlakuan dan empat kali pengulangan. Teknik pengumpulan data dalam penelitian ini menggunakan ANAVA (analisis variansi) satu jalan sel sama.

\section{HASIL DAN PEMBAHASAN}

Hasil Uji Organoleptik (Rasa, Warna, Aroma dan Tekstur) Tempe Kedelai didapatkan bahwa rasa tempe didapatkan rata-rata (3.47) dikemas dengan daun pepaya, (3.35) dikemas dengan daun talas dan (3.07) dikemas dengan daun pisang, sehingga bisa dilihat dari semua perlakuan hasil rata-rata rasa dari tempe kedelai memiliki rasa yang enak. Warna tempe didapatkan rata-rata (3.62) dikemas dengan daun pepaya, (3.65) dikemas dengan daun talas dan (3.63) dikemas dengan daun pisang, sehingga bisa dilihat dari semua perlakuan hasil rata-rata warna dari tempe kedelai memiliki warna putih. Aroma tempe didapatkan rata-rata (3.23) dikemas dengan daun pepaya, (3.20) dikemas dengan daun talas dan (2.83) dikemas dengan daun pisang, sehingga bisa dilihat dari semua perlakuan hasil rata-rata rasa dari tempe kedelai memiliki aroma khas tempe pada daun pepaya dan daun talas, untuk daun pisang memilki aroma kurang khas tempe. Tekstur tempe didapatkan rata-rata (3.38) dikemas dengan daun pepaya, (3.67) dikemas dengan daun talas dan (3.35) dikemas dengan daun pisang, sehingga bisa dilihat dari semua perlakuan hasil rata- rata tekstur dari tempe kedelai memiliki tekstur keras dikemas dengan daun talas, tekstur cukup keras dikemas dengan daun pepaya dan daun pisang.

Selanjutnya untuk mengetahui Hasil Uji Hipotesis Analisis Sidik Ragam

Anava Tempe Kedelai untuk rasa didapatkan hasil $\mathrm{F}$ hitung $>\mathrm{F}$ tabel yaitu 


\section{$4,99>$}

3,15. Jadi, ada pengaruh jenis bahan kemasan dari daun pepaya, daun talas dan daun pisang terhadap kualitas organoleptik rasa tempe kedelai pada perlakuan. Warna didapatkan $\mathrm{F}$ hitung $<\mathrm{F}$ tabel yaitu $0,10<3.15$ jadi, tidak ada pengaruh jenis bahan kemasan dari daun pepaya, daun talas dan daun pisang terhadap kualitas organoleptik warna tempe kedelai pada perlakuan. Aroma didapatkan F hitung > F tabel yaitu 3,89

$>3.15$ jadi, ada pengaruh jenis bahan kemasan dari daun pepaya, daun talas dan daun pisang terhadap kualitas organoleptik aroma tempe kedelai pada perlakuan. Tekstur didapatkan F hitung > F tabel yaitu 5,81 > 3,15 Jadi, ada pengaruh jenis bahan kemasan dari daun pepaya, daun talas dan daun pisang terhadap kualitas organoleptik aroma tempe kedelai pada perlakuan.

Rasa tempe kedelai yang dikemas daun pepaya karena rasa enak yang didapatkan lebih baik. Rasa yang timbul berasal dari tempe kedelai itu sendiri, tempe dikemas daun pepaya lebih banyak mengandung senyawa fenol yaitu senyawa aromatik yang menarik rasa dari tempe daun pepaya sehingga rasa dan aroma dari tempe dikemas oleh daun pepaya disukai panelis ( Fitria, dkk. 2013: 6-8). Warna khas tempe kedelai pada tiap perlakuan adalah putih disebabkan karena adanya miselia kapang yang tumbuh pada permukaan biji kedelai. Kemasan daun lebih putih karena kemasan daun kedap cahaya dan belum lama difermentasi sehingga kondisi kapang masih aktif dalam masa pertumbuhan (Sayuti, 2015: 155). Aroma dari tempe kedelai sama-sama memiliki aroma khas tempe akan tetapi tingkat kesukaan panelis lebih tinggi pada aroma tempe kedelai yang dikemas dengan daun pepaya. Karena daun pepaya lebih banyak mengandung senyawa fenol yang merupakan golongan senyawa aromatik (fitria, dkk. 2013: 4). Aroma khas tempe ditimbulkan karena adanya proses fermentasi dari kedelai, sedangkan aroma langu timbul disebabkan dari asam amino bebas dan penguraian lemak selama proses fermentasi berlangsung (Dini, 2016: 17). Tekstur dari tempe kedelai memiliki tekstur yang berbeda, dimana tekstur keras dikemas dengan daun talas, tekstur cukup keras dikemas dengan daun pepaya dan daun pisang. Tingkat kesukaan panelis tertinggi terhadap tekstur tempe kedelai terdapat pada tempe kedelai yang dikemas dengan daun talas. Tekstur keras tempe pada daun talas disebabkan oleh miselia-miselia kapang yang menghubungkan antara biji-biji kedelai, tekstur tempe dapat diketahui dengan meraba dan melihat lebat tidaknya miselia yang tumbuh pada permukaan tempe. Tempe yang memiliki tekstur yang keras disebabkan karena kapang miseliumnya sudah matang (Umami, dkk. 2018: 145-146 ).

Daya simpan tempe menggunakan kemasan daun seperti daun pepaya dan daun talas memiliki waktu simpan 3 hari, disebabkan karena daun pepaya memiliki senyawa alkaloid yaitu enzim papain yang berdifusi ke produk tempe sehingga terjadi pembusukan, daun talas memiliki lapisan lilin dipermukaan daunnya yang kedap tehadap air sehingga hasil uap air dari produk tempe tidak dapat terserap oleh daun sehingga air kembali di serap oleh tempe dan terjadi pembusukan, sedangkan daun pisang memiliki daya simpan 4 hari karena kondisi lembap dan tidak terjadi kondensasi uap air yang dihasilkan selama pertumbuhan miselium jamur (Sayuti,

2015: 157).

\section{SIMPULAN DAN SARAN}

Berdasarkan hasil analisis data dan pembahasan disimpulkan bahwa ada pengaruh jenis bahan kemasan terhadap kualitas organoleptik yang meliputi rasa, aroma dan tekstur tempe kedelai sedangkan untuk warna tidak ada pengaruh, kemudian untuk daya simpan tempe kedelai yang paling lama yaitu daun pisang lama penyimpanan 4 hari sedangkan daun talas dan daun pepaya lama penyimpanan 3 hari. hasil hipotesis dengan taraf signifikan 5\% menunjukkan bahwa pada hasil analisis dengan indikator rasa $\mathrm{F}$ hitung $>\mathrm{F}$ tabel $(4,99>3,15)$, indikator warna $F$ hitung $<F$ tabel $(0,10<3,15)$, indikator aroma F hitung $>\mathrm{F}$ tabel $(3,89>3,15)$, indikator tekstur $\mathrm{F}$ hitung $>\mathrm{F}$ tabel $(5,81>3,15)$.

\section{DAFTAR RUJUKAN}

Bisyria, Fatih., Zaenab, Siti., \& Rofieq, Ainur. (2015). Pengaruh Penambahan Berbagai Bahan Tambahan (Singkong, Pepaya, Nasi Aking) Dalam Berbagai Perbandingan 
Terhadap Kualitas Tempe Campuran Sebagai Media Leaflet Materi Bioteknologi SMA Kelas XII. Jurnal Pendidikan Biologi Indonesia. Volume 1, Nomor 2, hal. 138-147.

Dini, Ema Iga. (2016). Pengaruh Kemasan Pelepah Pisang Terhadap Mutu Dan Daya Cerna Protein In Vitro Tempe Kedelai (Glycine max). Institut Pertanian Bogor. Diunduhhttp://repository.ipb.ac.id/jspu i/bitstream/123456789/87000/1/I16ied. pdf diakses (17 juni 2020).

Fitria, Aini Nur., Sidi, Ciptaning Nurila., Safitri, Kartika Rina., Hasanah, Nur Annisa., \& Risni, Titis. (2013). Tempe Daun Pepaya Sebagai Alternatif Terapi Untuk Penderita Kanker. Jurnal Teknosains Pangan, Volume 2, Nomor 4, hal. 3-11.

Mufidah, Indahtul., Fathimah., Azizah, Nurul., \& Darni, Joyeti. (2018). Analisi Perbedaan Jenis Pembungkus Terhadap Kadar Proksimat Dan Daya Terima Tempe Biji Lamtoro (Leucaena Leucocephala). Darussalam Nuration Journal. Volume 2, Nomor 2, hal. 2131.

Razie, Fahrur., \& Widawati, Lina. (2018). Kombinasi Pengemasan Vakum Dan Ketebalan Kemasan Untuk Memperpanjang Umur Simpan Tempe. AGRITEPA. Volume IV, Nomor 2, hal. 94-107.

Sayuti. (2015). Pengaruh Bahan Kemasan Dan Lama Inkubasi Terhadap Kualitas Tempe Kacang Gude Sebagai Sumber Belajar IPA. Bioedukasi Jurnal Pendidikan Biologi. Volume 6, Nomor 2, hal.148-158.

Umami, Supriadi., Jaya, Swirya Ketut I., Darawati, Made., \& Widiada, Narda Gde I. (2018). Kajian Sifat Organoleptik Dan Masa Simpan Tempe Kedelai Dengan Beberapa Jenis Kemasan. Jurnal Gizi Prima. Volume 3, Nomor 2, hal. 142-148.

Winanti, Ruri., Bintari, Harnina Siti., \& Mustikaningtyas, Dewi. (2014). Studi Observasi Higienitas Produk Tempe Berdasarkan Perbedaan Metode
Inokulasi. Unnes Journal Of Life Science. Volume 3, Nomor 1, hal. 39-46. 